\begin{tabular}{|c|l|}
\hline Title & A quaculture performance of triploid barfin flounder V erasper moseri \\
\hline Author(s) & Mori, Tatsunari; Saito, Setsuo; Kishioka, Chiharu; A rai, Katsutoshi \\
\hline Citation & $\begin{array}{l}\text { Fisheries Science, 72(2), 270-277 } \\
\text { https://doi.org/10.1111j.1444 2906.2006.01148.x }\end{array}$ \\
\hline Issue Date & 2006 \\
\hline Doc URL & http://hdl.handle.net/2115/35214 \\
\hline Rights & ○ 2006 公益社団法人日本水産学会; @ 2006 The Japanese Society of Fisheries Science \\
\hline Type & article \\
\hline File Information & arai-108.pdf \\
\hline
\end{tabular}

Instructions for use 


\title{
Aquaculture performance of triploid barfin flounder Verasper moseri
}

\author{
TATSUnARI MORI, ${ }^{1 *}$ Setsuo SAITO, ${ }^{2}$ ChiHARU KISHIOKA ${ }^{3}$ AND Katsutoshi ARAI ${ }^{3}$ \\ ${ }^{1}$ Hokkaido Central Fisheries Experimental Station, Yoichi, Hokkaido 046-8555, ${ }^{2}$ Hokkaido Institute of \\ Mariculture, Shikabe, Hokkaido 041-1404, and ${ }^{3}$ Graduate School of Fisheries Sciences, Hokkaido University, \\ Hakodate 041-8611, Japan
}

\begin{abstract}
To evaluate the aquaculture performance of triploid barfin flounder Verasper moseri, the sex ratio, maturation, growth and the relative proportion of body parts were examined. The sex ratio of triploids was similar to diploids under communal rearing conditions, but the proportion of female diploids was higher than that of triploids under separate rearing conditions. The gonadosomatic index of triploid females was very low even during the spawning season, and the ovaries were rudimentary. These results suggest that triploid barfin flounder females were sterile. In addition, triploid males produced a small quantity of milt containing very few spermatozoa with abnormal shapes. Spermatozoa obtained from triploids were aneuploidies. When normal eggs were fertilized with sperm from triploid males, no fry developed. These results suggest that triploid barfin flounder males were functionally sterile. Triploid males grew more slowly than diploid males, and triploid females showed similar or slower growth than diploid females, whether reared separately (23 months) or communally (35 months). The ratios of visceral weight to the edible parts for triploid males were similar to those for diploid males, but ratios for triploid females were higher than for diploid females during the spawning period. In conclusion, a significant improvement of growth was not found in triploid barfin flounders.
\end{abstract}

KEY WORDS: aneuploid sperm, barfin flounder, growth, GSI, sterility, triploid.

\section{INTRODUCTION}

The barfin flounder Verasper moseri is a large flatfish species, mainly inhabiting cold sea basins around the east coast of Hokkaido, Japan. This species is important for aquaculture in northern Japan because of high commercial value and high growth rate, even at low water temperatures. ${ }^{1}$

Generally, induced triploidy is expected not only to control undesirable reproduction, but also to improve growth, survival and meat quality due to the sterility of gonads. ${ }^{2,3}$ According to a recent review on triploidy in teleost fish by Felip et $a l^{3}$ the growth of triploids depends on factors such as species, age, sex and rearing conditions. In marine species, studies on growth of induced triploids have yielded varying results among different species. Triploid hybrid flatfish between female plaice Pleuronectes platessa and male flounder Platichthys flesus grew faster than the counterpart diploid hybrids. ${ }^{4}$ However, in Japanese flounder Paralich-

\footnotetext{
*Corresponding author: Tel: 81-135-23-8701.

Fax: 81-135-23-3141. Email: morit@fishexp.pref.hokkaido.jp Received 25 July 2005. Accepted 11 October 2005.
}

thys olivaceus, ${ }^{5,6}$ Japanese parrot fish Oplegnathus fasciatus $^{7}$ and European sea bass Dicentrarchus labrax, ${ }^{8,9}$ triploids showed similar growth to diploids in the juvenile stage and adult triploids grew more slowly than counterpart diploids even in the spawning season. Slower growth of triploids was also reported in adult red sea bream Pagrus major. ${ }^{10}$

With regard to sexual maturation, most triploid marine female fish are sterile and rudimentary ovaries were observed in plaice flounder, ${ }^{4}$ Japanese flounder, ${ }^{5,6}$ Japanese parrot fish, ${ }^{7}$ and European sea bass, ${ }^{8}$ as reported in many freshwater species. ${ }^{2}$ In some species examined, triploid males demonstrated sexual maturation with regular courtship, and produce a small quantity of aneuploid sperm, often exhibiting an unusual shape..$^{5-7,11-14}$

In barfin flounder, triploids have been successfully induced by inhibition of the second polar body extrusion after normal fertilization by temperature and pressure shock. ${ }^{15}$ However, the aquaculture performance of triploids has not yet been evaluated. In the present study, the sex ratio, maturation, growth and the relative proportion of several body parts of triploid barfin flounder were examined. 
Table 1 Identification numbers of parental fishes, treatment for inducing triploids, and sex ratios in control and triploid progeny in different rearing experiments

\begin{tabular}{|c|c|c|c|c|c|c|c|c|c|}
\hline \multirow{2}{*}{$\begin{array}{l}\text { Exp. } \\
\#\end{array}$} & \multirow{2}{*}{$\begin{array}{c}\text { Female } \\
\text { \# }\end{array}$} & \multirow{2}{*}{$\underset{\#}{\text { Male }}$} & \multirow[b]{2}{*}{ Treatment } & \multirow{2}{*}{$\begin{array}{l}\text { Progeny } \\
\text { group }\end{array}$} & \multicolumn{2}{|c|}{$\begin{array}{l}\text { Rearing condition } \\
\text { (months) }\end{array}$} & \multicolumn{2}{|c|}{ Sex of progeny } & \multirow[b]{2}{*}{ Female (\%) } \\
\hline & & & & & $0-6^{*}$ & 6-End ${ }^{+}$ & Female & Male & \\
\hline 1 & 1 & 1 & $650 \mathrm{~kg} / \mathrm{cm}^{2}, 6 \mathrm{~min}$ & $3 \mathrm{~N}$ & Separate & Communal & 14 & 49 & 22.2 \\
\hline & 2 & 1 & - & $2 \mathrm{~N}$ & & & 13 & 53 & 19.7 \\
\hline 2 & 3 & 2 & $-1.5^{\circ} \mathrm{C}, 90 \mathrm{~min}$ & $\begin{array}{l}3 \mathrm{~N} \\
2 \mathrm{~N}^{\dagger}\end{array}$ & Communal & Separate & $\begin{array}{l}13 \\
23\end{array}$ & $\begin{array}{r}16 \\
9\end{array}$ & $\begin{array}{l}44.8 \\
71.9\end{array}$ \\
\hline
\end{tabular}

${ }^{\dagger}$ Misinduced diploids occurred following cold shock treatment for inducing triploids.

${ }^{\ddagger}$ At the age of 35 months after hatching in Exp. 1 and at 23 months after hatching in Exp. 2.

\section{MATERIALS AND METHODS}

\section{Broodstock and induction of triploids}

Barfin flounder (three females, identification No. $1-3$, age $3+, 505 \mathrm{~mm}$ mean total length; two males, identification No. 1-2, age 3+, $440 \mathrm{~mm}$ mean total length) were transported from the Hokkaido Institute of Mariculture, Shikabe, Hokkaido to the Hokkaido Central Fisheries Experimental Station, Yoichi, Hokkaido, and were reared in a $4 \mathrm{~kL}$ tank. Fertilized eggs were obtained by artificial fertilization. ${ }^{16}$ In Experiment (Exp.) 1, triploids were induced in fertilized eggs obtained from a cross between female \#1 and male \#1, by pressure shock $\left(0.650 \mathrm{~N} / \mathrm{m}^{2}, 6 \mathrm{~min}\right.$ duration) at $6 \mathrm{~min}$ after fertilization. To produce control diploids, eggs from female \#2 were inseminated with sperm from male \#1 (Table 1). In Exp. 2, triploids were obtained from the cross between female \#3 and male \#2 by cold shock $\left(-1.5^{\circ} \mathrm{C}\right.$ for $\left.90 \mathrm{~min}\right)$ starting at $7 \mathrm{~min}$ after fertilization, according to the technique described previously. ${ }^{15}$ Misinduced diploids (specimens that did not become triploids but developed as diploids) occurred from the cold shock treatment and were used as control diploids in this experiment (Table 1).

\section{Rearing conditions}

In both experiments, embryos of control diploids and triploids were incubated in different polycarbonate tanks $(100 \mathrm{~L})$ at $8-10^{\circ} \mathrm{C}$. Rearing water temperature was gradually increased up to $14^{\circ} \mathrm{C}$ by 55 days post hatching (dph) and was maintained until $120 \mathrm{dph}$. Hatched larvae were fed with rotifers between 9-55 dph and Artemia nauplii between 20-75 dph, which were enriched with docosahexaenoic acid by Marine Glos (Nisshin Marinetech Co, Yokohama, Japan). From 65-175 dph
( $\sim 6$ months after hatching), fish were fed with a commercial diet (Marubeni Nisshin Feed Co, Tokyo, Japan) three to four times per day. From 6 months, fish were fed with a commercial diet twice a day and were transferred to different tanks with larger volumes depending on their age and growth. Fish were reared under natural water temperature ranging from $4.5^{\circ} \mathrm{C}$ in winter to $23.8^{\circ} \mathrm{C}$ in summer.

In Exp. 1, fish were reared under separate conditions from the age of 0 to 6 months. At 6 months, diploids $(n=140)$ and triploids $(n=130)$ were sampled to be tagged individually, and then mixed in the same tank until the end of experiment (35 months) (Table 1). In Exp. 2, triploids and misinduced diploids were reared communally in the same tank from 0 to 6 months. At 6 months, diploids $(n=33)$ and triploids $(n=33)$ were tagged individually, and then each ploidy group was kept in different tanks until the end of experiment (23 months) (Table 1).

\section{Ploidy determination}

At 6 months, the ploidy of fishes was flowcytometrically determined by measuring the relative DNA content of blood cells. A blood sample was taken from the caudal vein of each individual with a syringe, and then fixed with $70 \%$ ethanol. Further preparation for the measurement procedure was done according to a previous study. ${ }^{15}$

\section{Observation of sex ratios}

In Exp. 1, 63 diploids and 66 triploids were sampled and their gonads were examined at 6 months. In Exp. 2, gonads of all survivors were dissected at the end of experiment. Sex was examined by observing 
the external shape of gonads by eye according to Goto et al. ${ }^{17}$

\section{GSI and sperm morphology}

Four to 10 fishes of each sex and ploidy were sampled at 23 and 35 months in Exp. 1. Fish were killed and their gonads were dissected and weighed. Gonadosomatic index (GSI) was calculated by the formula: GSI $=($ gonad weight $/$ body weight $) \times 100$.

In males, 16-21 fishes from each ploidy group of Exp. 1 were taken from the tank and the spermiation was checked by squeezing the abdomen. Milt collected from diploid $(n=4)$ and triploid $(n=4)$. individuals at 35 months were preserved in Ringer's solution (140.7 mM NaCl, $5.2 \mathrm{mM} \mathrm{KCl}$, $4.9 \mathrm{mM} \mathrm{CaCl}_{2} \cdot 2 \mathrm{H}_{2} \mathrm{O}, 1.1 \mathrm{mM} \mathrm{MgCl} \cdot 6 \mathrm{H}_{2} \mathrm{O}, 1.8 \mathrm{mM}$ $\mathrm{NaH}_{2} \mathrm{PO}_{4} \cdot 2 \mathrm{H}_{2} \mathrm{O}, 2.4 \mathrm{mM} \mathrm{NaHCO} 3,5.6 \mathrm{mM}$ glucose, $\mathrm{pH}$ 6.0) and used for ploidy determination by flow-cytometry. At the same time, a sample of semen was fixed in $2.5 \%$ glutaraldehyde and rinsed in $t$-butanol. Sperm morphology was then observed with a scanning electron microscope (SEM) (Hitachi S-2460N, Tokyo, Japan) at $10 \mathrm{kV}$ accelerating voltage. The major-axis diameters of sperm heads were measured from SEM images. Mature eggs ( $8 \mathrm{~g}$ replicates) taken from a mature diploid female were fertilized with semen from diploid and triploid individuals and the appearance of hatched larvae was observed at 10 days after fertilization.

\section{Growth performance}

In Exp. 1, body weight (BW) and gonad weight were measured to $\pm 0.1 \mathrm{~g}$, and BW excepting the gonad (BWEG $=$ BW - gonad weight) was calculated at 23 and 35 months. In Exp. 2, BW and gonad weight were measured and BWEG was calculated at 23 months. At the end of Exp. 2, all survivors of each ploidy were counted and survival rates from 6 to 23 months were determined.

\section{Relative proportion of body parts}

The proportion of several body parts was measured at the first spawning period (35 months) in Exp. 1. Five females and five males in each ploidy were killed and BW, visceral weight, dorsal muscle weight and ventral muscle weight were measured. The ratio (\%) of visceral weight to BW, and the ratio $(\%)$ of edible parts = dorsal muscle weight + ventral muscle weight) $/ \mathrm{BW} \times 100$, were calculated.

\section{Statistics}

Deviations in sex ratio from the theoretical $1: 1$ (female-male) ratio in diploid and triploid groups were analyzed by a $\chi^{2}$-test. The survival rate between diploids and triploids was also checked by a $\chi^{2}$-test. The data for BW, BWEG, the sperm head length and the proportion of body parts were analyzed by a Student's $t$-test. The GSI data were analyzed by a Wilcoxon rank sum test. Probability ( $P$-values) less than 0.05 were regarded as statistically significant.

\section{RESULTS}

\section{Sex ratios}

In Exp. 1, the proportions of female diploids and triploids were $19.7 \%(n=66)$ and $22.2 \%(n=63)$ of the total, respectively. No significant difference was detected between the two ploidies (Table 1). However, the occurrence of females was significantly lower than the theoretical $1: 1$ ratio. In Exp. 2, diploids exhibited a significantly higher female ratio $(71.9 \%, n=29)$ but triploids indicated a normal sex ratio $(44.8 \%, n=32)$.

\section{GSI and sperm morphology}

The GSIs of females are shown in Figure 1. There was no difference in female GSIs between diploids and triploids at 23 months $(P<0.05)$. At 35 months, the mean GSI of female diploids was 23.4. In con- (a)

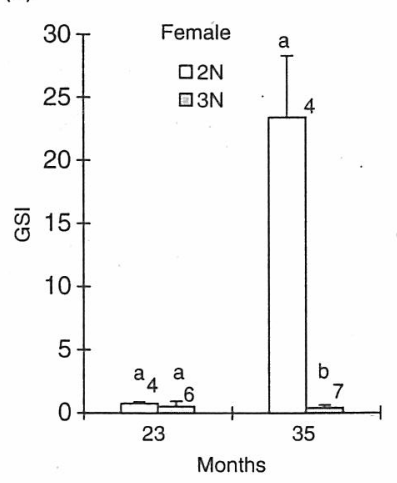

(b)

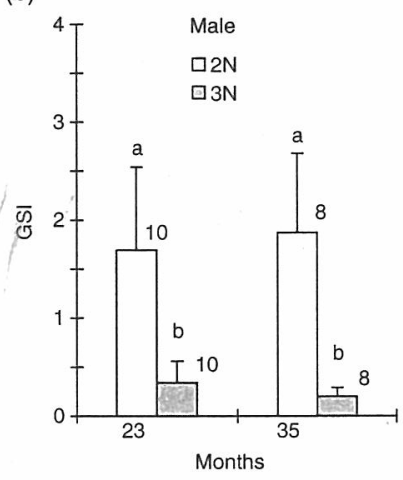

Fig. 1 Gonadosomatic index (GSI) of both sexes in triploid and diploid barfin flounder at the age of 23 and 35 months after hatching. (a) females, (b) males. Vertical bars indicate standard deviation of the means. The numbers on bars indicate the sample size. Different letters on bars show a significant difference at $P<0.05$ within the same months. 
Fig. 2 Electron micrographs of spermatozoa in (a) diploid and (b), (c), (d) triploid fish. Scale indicates $2 \mu \mathrm{m}$ in (a), $5 \mu \mathrm{m}$ in (b), (c), and (d). (a)

(c)
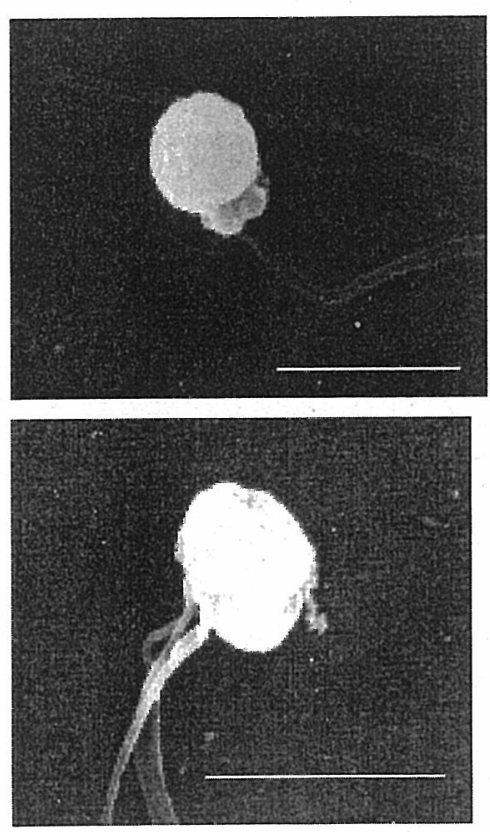

(b)

(d)
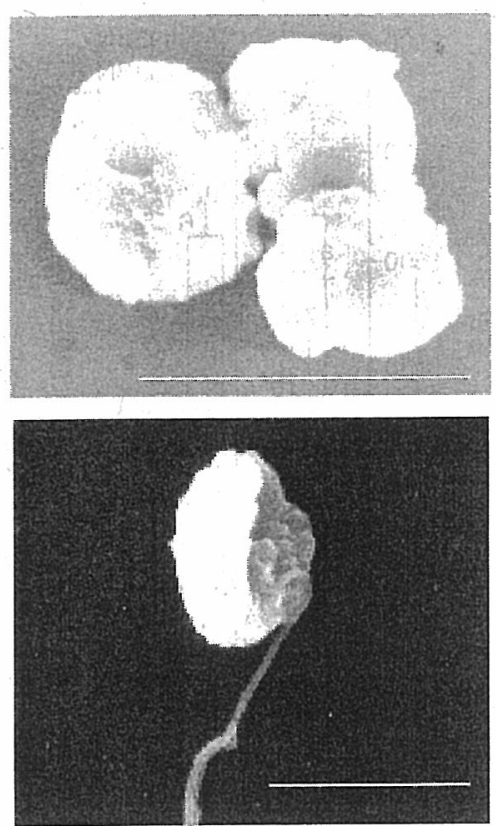

trast, triploid females had rudimentary ovaries when compared to diploids and the GSIs of triploids were extremely low (0.1-0.6). The GSIs of males are also shown in Figure 1. The GSIs of triploids were significantly lower than those of diploids at 23 months $(P<0.05)$. A similar trend was seen at 35 months, the GSIs of triploids were lower than those of diploids $(P<0.05)$.

At 23 months, $80.0 \%$ of diploids $(n=20)$ reached maturation and showed spermiation. In contrast, no triploid exhibited spermiation. At 35 months, $90.5 \%$ of diploids $(n=21)$ exhibited active spermiation, while $43.8 \%$ of triploids $(n=16)$ produced very small amounts of semen after firm pressure was applied to the abdomen. The SEM observation revealed that spermatozoa of triploids had morphological abnormalities such as no flagellum (Fig. 2b), double heads (Fig. 2c) and head malformation (Fig. 2d) when compared to spermatozoa of normal male (Fig. 2a). Average head length of spermatozoa taken from triploids $(4.88 \pm 1.93 \mu \mathrm{m})$ was significantly larger $(P<0.05)$ than that of normal diploids $(1.63 \pm 0.08 \mu \mathrm{m})$.

In flow cytometry, the mean peaks from blood from diploids and triploids were 101.9 and 151.5 channel number, respectively. The triploid-diploid ratio in the mean DNA content was 1.49. The mean peak of semen from diploids was 47.8 (peak 1 ) and triploids 68.2 (peak 2), respectively. The triploiddiploid ratio in the mean DNA content of semen was 1.43 , indicating about $1.5 \mathrm{n}$ aneuploidy. Semen collected from triploids had a range of channel numbers when compared with diploids as shown in Figure 3 . The mean coefficient of variation
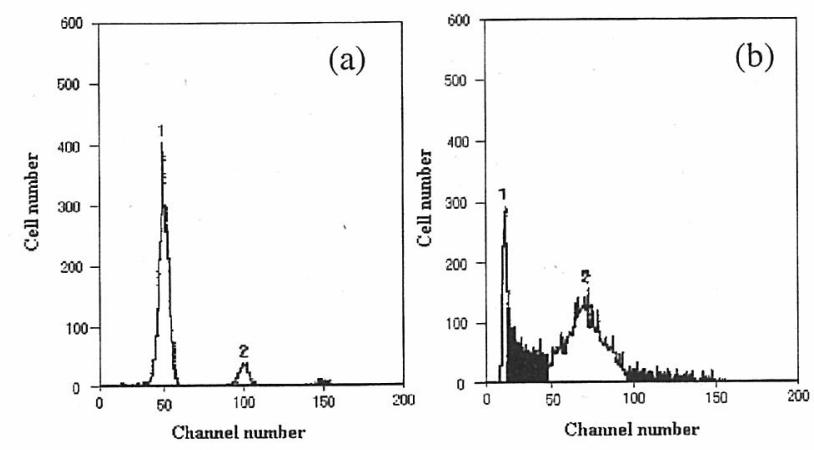

Fig. 3 Relative DNA contents flow-cytometrically measured in semen collected from (a) diploid and (b) triploid barfin flounder. 1, 2 refer to peak number.

$(\mathrm{CV} \%=$ standard deviation of a peak/mean of a peak $\times 100)$ of semen collected from triploids (15.47) was greater than that from diploids (4.06). When mature eggs of normal diploid females were fertilized with semen of triploid individuals, no fry were obtained.

\section{Growth performance}

In Exp. 1 (Fig. 4), BW and BWEG of females were not significantly different between diploids and triploids at 23 months. At 35 months, BW of triploid females was significantly smaller than diploids $(P<0.05)$, but no significant difference was observed in BWEG between diploids and triploids. In males, BW and BWEG of triploids were signifi- 
(a)

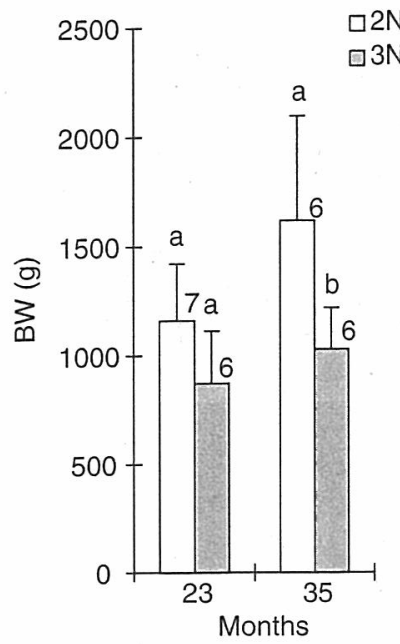

(b)

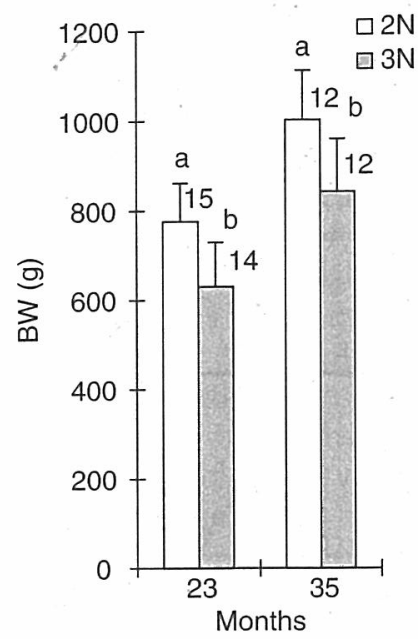

Female

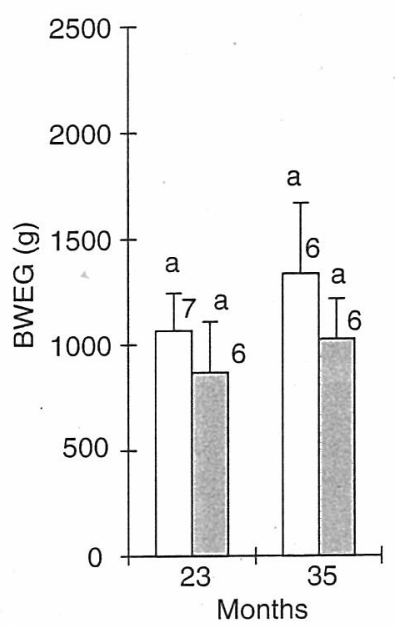

Male

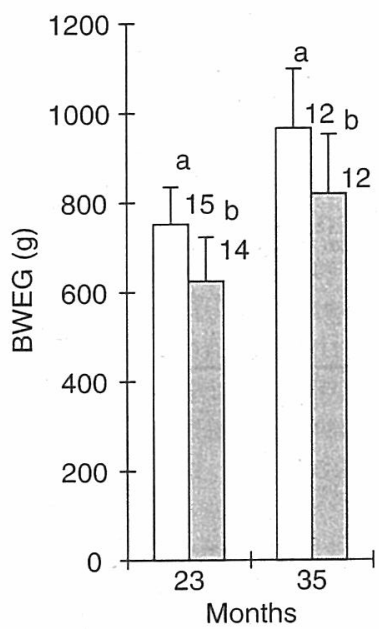

Fig. 4 Body weight (BW) and body weight excepting gonad (BWEG) for triploid and diploid barfin flounder at the age of 23 and 35 months after hatching in Experiment 1. (a) females, (b) males. Vertical bars indicate standard deviation of the means. Numbers on bars indicate the sample size. Different letters on bars show a significant difference at $P<0.05$ within the same months.

cantly smaller than those of diploids at 23 and 35 months $(P<0.05)$. In both ploidies, BW and BWEG of females were greater than those of males at 23 and 35 months.

In Exp. 2 (Fig. 5), BW and BWEG of triploids were significantly smaller than those of diploids at 23 months in both sexes $(P<0.05)$. As in Exp. 1, BW and BWEG of females were greater than those of males. No significant difference was found in survival rates between diploids (96.7\%) and triploids (90.9\%) from 6 to 23 months.

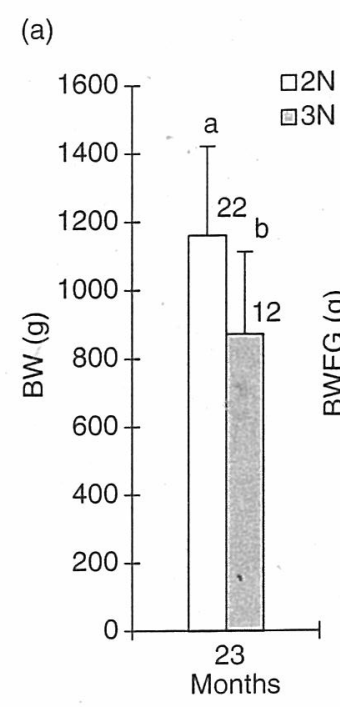

Female

(b)

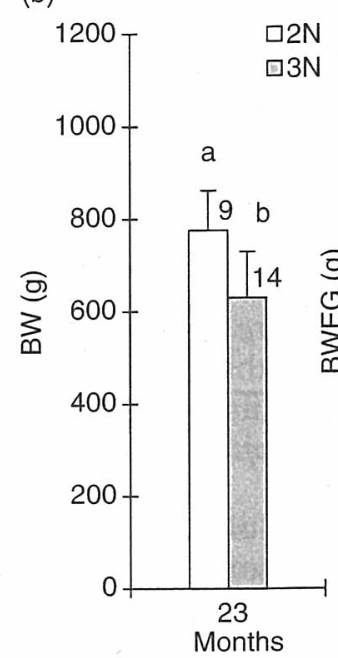

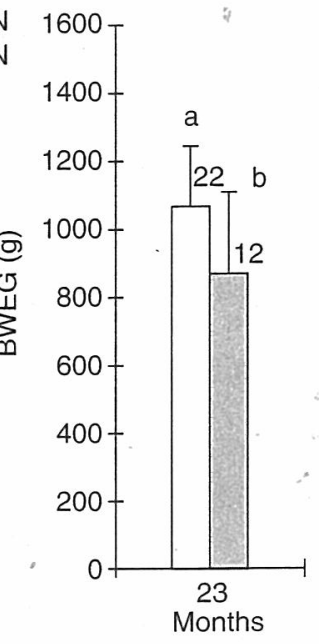

Male

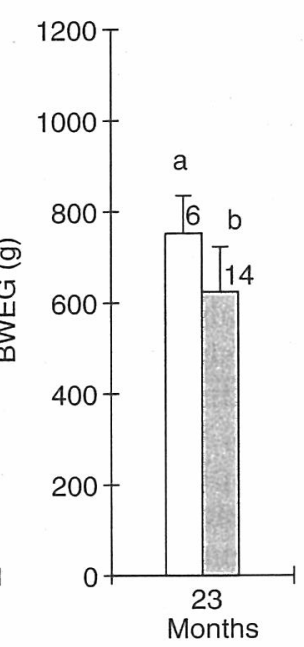

Fig. 5 Body weight (BW) and body weight excepting gonad (BWEG) for triploid and diploid barfin flounder at the age of 23 months after hatching in Experiment 2. (a) females, (b) males. Vertical bars indicate standard deviation of the means. Numbers on bars indicate the sample size. Different letters on bars show a significant difference at $P<0.05$.

\section{Relative proportion of body parts}

In Exp. 1, there was no significant difference in the ratio of visceral weight to body weight between diploid males and triploid males. However, triploid females had a significantly higher ratio of visceral weight than diploid females $(P<0.05)$ (Fig. 6). In the ratio of edible parts to body weight, male diploids were similar to triploids, while female triploids gave higher ratios than diploids at 35 months $(P<0.05)$ (Fig. 7). 

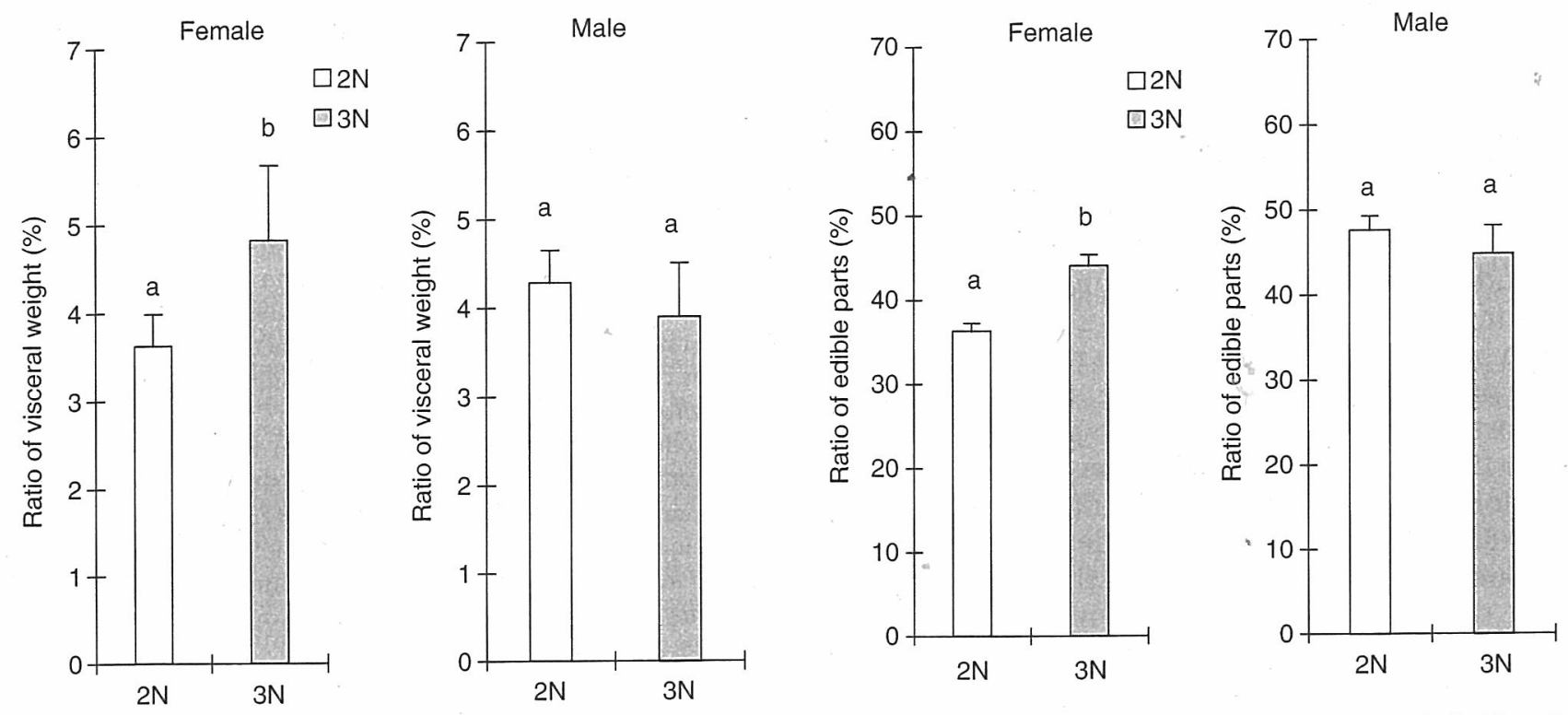

Fig. 6 Ratio of visceral weight of both sexes in triploid and diploid barfin flounder at the age of 35 months after hatching. Vertical bars indicate standard deviation of the means. Different letters on bars show a significant difference at $P<0.05$.

\section{DISCUSSION}

The sex ratio of several fish species fluctuates due to environmental factors. ${ }^{18}$ In Japanese flounder, sex reversal from genetic female to physiological male frequently occurs not only at high water temperature but also in low temperature conditions. ${ }^{19}$ In barfin flounder, the rearing temperature at the stage of $10-35 \mathrm{~mm}$ in total length is critical for gonadal sex differentiation, and water temperature below $14^{\circ} \mathrm{C}$ yielded almost a 1:1 sex ratio in a previous study. ${ }^{17}$ The sex ratio was similar between diploids and triploids in Exp. 1, although the percentage of females was significantly lower than the theoretical $1: 1$ sex ratio even at $14^{\circ} \mathrm{C}$. In this study, other environmental ${ }^{20}$ or genetic factors such as maternal effect ${ }^{21,22}$ might have affected the sex ratios of both diploids and triploids. However, in Exp. 2, diploids had a higher female ratio than triploids and there were significantly more females than for a theoretical 1:1 sex ratio. In this study, social factors such as interference between diploids and triploids might have influenced the sex ratio, because diploid and triploid fish were communally reared in Exp. 2. However, the reason for the high female ratio in diploids remains unclear. Further research is required to identify factors other than the rearing temperature that affect sex differentiation in barfin flounder.

Fig. 7 Ratio of edible parts of both sexes in triploid and diploid barfin flounder at the age of 35 months after hatching. Vertical bars indicate standard deviation of the means. Different letters on bars show a significant difference at $P<0.05$.

The GSI of triploid females was very low even during the spawning season and the gonads of all examined fishes were rudimentary. These results indicated that triploid barfin flounder females were sterile at least up to 35 months after hatching. Similar results have already been obtained in other marine fishes, such as Japanese flounder, 5,6 Japanese parrot fish ${ }^{7}$ and European sea bass. ${ }^{8}$ In yellowtail flounder Limanda ferruginea, maturation of triploids was slower than that of diploid fishes. ${ }^{23}$

In this study, triploid males produced a small quantity of milt containing very few spermatozoa, as reported in Japanese flounder. ${ }^{5,6}$ The SEM observation revealed that sperm head lengths of spermatozoa from triploid males were larger than those of diploids and most sperm exhibited abnormal morphology. Abnormal shapes of sperm were also reported in rainbow trout, ${ }^{11}$ Japanese flounder ${ }^{5}$ and red sea bream. ${ }^{24}$ The flow-cytometric analysis of the present study revealed that the sperm of triploids were aneuploidies around 1.5n. Aneuploidies of sperm were detected in triploids of rainbow trout, $^{12}$ red sea bream, ${ }^{24}$ loach Misgurnus anguillicaudatus $^{25}$ and rosy bitterling Rhodeus ocellatus ocellatus. ${ }^{26}$ In the present study, no fry developed when normal eggs were fertilized with abnormal sperm collected from triploid males. Several studies have also reported that sperm obtained from triploids exhibited poor fertility in 
fertilization tests. ${ }^{5,11,23}$ Therefore, triploid males of barfin flounder were functionally sterile.

Kobayashi and Fushiki ${ }^{27}$ explained the lower growth rate of triploid rainbow trout by competition for food between diploids and triploids undêr communal rearing conditions. In the present study, similar trends in growth performance were found between the separate and the communal rearing conditions.

In barfin flounder, the growth rate of diploids in the maturation and spawning season has been reported to be very low ${ }^{28}$ due to the low temperature $\left(5-8^{\circ} \mathrm{C}\right)$. Therefore, it is possible that even if triploids have a growth advantage, the energy related to growth is stored as a deposit somewhere

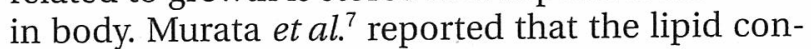
tent of viscera and abdominal muscle in triploid Japanese parrot fish increased in the spawning season compared to diploid fish, and they suggested that the energy otherwise used for maturation and spawning in diploids was stored in triploids as lipids. Thus, the chemical compositions of each body part need to be measured in the maturation and spawning period of both ploidies. Such a study may clarify the reason of the lack of growth improvement in triploid barfin flounders.

In the relative proportion of edible parts to total body weight, male triploids were similar to diploids. However, female triploids had higher percentages of edible parts than female diploids during the spawning period. Ueno et al. ${ }^{29}$ reported that the edible portion of triploid ayu Plecoglossus altivelis females and males were $30 \%$ and $15 \%$, respectively, larger than those of diploids. Similar results were also obtained in rainbow trout ${ }^{30}$ and Japanese parrot fish. ${ }^{7}$ In the present study, the edible portion of triploid females was greater than in diploids. However, the weight of the edible portion of triploid females was smaller than for diploid females. Consequently, improvement in growth was not detected in triploid barfin flounder. The possible advantage of all-female triploids still remains because female triploids were sterile and the growth rate of females was remarkably better than males. For utilization of triploid barfin flounder in aquaculture, meat quality, taste and texture are required to be elucidated in the future.

\section{ACKNOWLEDGMENTS}

Thanks to the staff of Hokkaido Institute of Mariculture for their help in collecting mature eggs, and to the staff of Hokkaido Central Fisheries Experimental Station for their help in rearing fishes. This study was supported in part by a Grant-in-Aid for 21st Century Center of Excellence (COE) Programs from the Ministry of Education, Culture, Sports, Science and Technology (MEXT), Japan.

\section{REFERENCES}

1. Ando T, Watanabe K, Matsubara T. Problems and perspectives in stock enhancement of barfin flounder (Reviews). Bull. Hokkaido Natl. Fish. Res. Inst. 1999; 63: 19-33.

2. Arai K. Genetic improvement of aquaculture finfish species by chromosome manipulation techniques in Japan. Aquaculture 2001; 197: 205-228.

3. Felip A, Zanuy S, Carrillo M, Piferrer F. Induction of triploidy and gynogenesis in teleost fish with emphasis on marine species. Genetica 2001; 111: 175-195.

4. Lincoln RF. The growth of female diploid and triploid plaice (Pleuronectes platessa) and plaice flounder (Platichthys flesus) hybrids over one spawning season. Aquaculture 1981; 25: 259-268.

5. Tabata K, Gorie S, Kawamura Y. Growth, survival and maturation in the induced triploid hirame Paralichthys olivaceus. Suisanzoshoku 1989; 36: 267-276.

6. Yamamoto E. Application of gynogenesis and triploidy in hirame (Paralichthys olivaceus) breeding. Fish Genet. Breed. Sci. 1992; 18: 13-23.

7. Murata O, Kato K, Ishibashi Y, Miyashita S, Nasu T, Ikeda S, Kumai H. Comparison of growth and chemical composition between diploid and triploid in Japanese parrot fish. Suisanzoshoku 1994; 42: 411-418.

8. Felip A, Zanuy S, Carrillo M, Piferrer F. Growth and gonadal development in triploid sea bass (Dicentrarchus labrax L.) during the first two years of age. Aquaculture 1999; 173: 389-399.

9. Felip A, Piferrer F, Zanuy S, Carrillo M. Comparative growth performance of diploid and triploid European sea bass over the first four spawning seasons. J. Fish Biol. 2001; 58: 76-88.

10. Murata O. Studies on the breeding of cultivated marine fishes. Bull. Fish. Lab. Kinki Univ. 1998; 6: 1-101.

11. Okada H. Studies on the artificial sex control in rainbow trout, Salmo gairdneri. Sci. Rep. Hokkaido Fish Hatchery 1985; 40: 1-49.

12. Benfey TJ, Solar II, Jong G, Donaldson EM. Flow-cytometric confirmation of aneuploidy in sperm from triploid rainbow trout. Trans. Am. Fish. Soc. 1986; 115: 838-840.

13. Kitamura H, Teong OY, Arakawa T. Gonadal development of artificially induced triploid red sea bream Pagrus major. Nippon Suisan Gakkaishi 1991; 57: 1657-1660.

14. Kitamura S, Ogata H, Onozato H. Triploid male masu salmon Oncorhynchus masou shows normal courtship behavior. Nippon Suisan Gakkaishi 1991; 57: 2157.

15. Mori T, Saito S, Kishioka C, Arai K. Induction of triploids and gynogenetic diploids in barfin flounder Verasper moseri. Nippon Suisan Gakkaishi 2004; 70: 145-151 (in Japanese).

16. Koya Y, Matsubara T, Nakagawa T. Efficient artificial fertilization method based on the ovulation cycle in barfin flounder Verasper moseri. Fish. Sci. 1994; 60: 537-540.

17. Goto R, Mori T, Kawamata K, Matsubara T, Mizuno S, Adachi $\mathrm{S}$, Yamauchi $\mathrm{K}$. Effects of temperature on gonadal sex determination in barfin flounder Verasper moseri. Fish. Sci. 1999; 65: 884-887. 
18. Devlin RH, Nagahama Y. Sex determination and sex differentiation in fish: an overview of genetic, physiological, and environmental influences. Aquaculture 2002; 208: 191364.

19. Yamamoto E. Studies on sex-manipulation and production of cloned populations in hirame, Paralichthys olivaceus (Temminck et Schlegel). Aquaculture 1999; 173: 235-246.

20. Rubin DA. Effect of $\mathrm{pH}$ on sex determination in cichlids and a poeciliid (Teleostei). Copeia 1985; 1: 233-235.

21. Conover DO, Kynard BE. Environmental sex determination: interaction of temperature and genotype in a fish. Science 1981; 213: 577-579.

22. Shultz RJ. Genetic regulation of temperature-mediated sex ratios in the livebearing fish Poeciliopsis lucida. Copeia 1993; 4: 1148-1151.

23. Manning AJ, Burton MPM, Crim LW. Reproductive evaluation of triploid yellowtail flounder, Limanda ferruginea (Storer). Aquaculture 2004; 242: 625-640.

24. Kawamura K, Hosoya K, Fukusho K. Spermatozoa of artificially induced triploid red sea bream Pagrus major (Temminck and Schlegel). Fish. Sci. 1995; 61: 355-356.
25. Zhang Q, Arai K. Aberrant meioses and viable aneuploid progeny of induced triploid loach (Misgurnus anguillicaudatus) when crossed to natural tetraploids. Aquaculture 1999; 175: 63-76.

26. Kawamura K, Ueda T, Aoki K, Hosoya K. Spermatozoa in triploids of the rosy bitterling Rhodeus ocellatus ocellatus. J. Fish Biol. 1999; 55: 420-432.

27. Kobayashi T, Fushiki S. The competition for food between triploids and diploids and its effect on the growth of triploids in rainbow trout. Suisanzoshoku 1997; 45: 87-96.

28. Kayaba T, Sugimoto T, Satoh N, Ozaki Y, Adachi S, Takamaru N, Yamauchi K. Synchronization of gonadal maturation among sexes in barfin flounder Verasper moseri by water temperature manipulation. Sci. Rep. Hokkaido Fish. Exp. Stn. 2000; 58: 9-16.

29. Ueno K, Ikenaga $Y$, Kariya $\mathrm{H}_{2}$ Potentiality of application of triploidy to the culture of ayu, Plecoglossus altivelis Temminck et Schlegel. Jpn. J. Genet 1986; 61: 71-77.

30. Kobayashi T. Growth, survival and reproductive cycle of induced triploid rainbow trout under the communal rearing condition with diploid for long period. Suisanzoshoku 1992; 40: 47-70. 